\title{
Honokiol, a phytochemical from Magnolia spp., inhibits breast cancer cell migration by targeting nitric oxide and cyclooxygenase-2
}

\author{
TRIPTI SINGH ${ }^{2}$ and SANTOSH K. KATIYAR ${ }^{1,2,3,4}$ \\ ${ }^{1}$ Birmingham Veterans Affairs Medical Center, Birmingham, AL; ${ }^{2}$ Department of Dermatology; \\ ${ }^{3}$ Comprehensive Cancer Center; ${ }^{4}$ Nutrition Obesity Research Center, \\ University of Alabama at Birmingham, Birmingham, AL 35294, USA
}

Received October 13, 2010; Accepted November 22, 2010

DOI: $10.3892 /$ ijo.2011.899

\begin{abstract}
In the present study, we report the effects of honokiol, a phytochemical from Magnolia spp., on cancer cell migration capacity and the molecular mechanisms underlying these effects using breast cancer cell lines as an in vitro model. Using cell migration assays, we found that the treatment of human breast cancer cells (MCF-7) and murine mammary cancer cells (4T1) with honokiol resulted in a dose-dependent inhibition of migration of these cells, which was associated with a reduction in nitric oxide (NO) levels. The cell migration capacity was decreased in the presence of $\mathrm{N}^{\mathrm{G}}$-nitro-L-arginine methyl ester (L-NAME), an inhibitor of NO synthase. Honokiol reduced the elevated levels of cyclic guanosine monophosphate (cGMP) in the cells, while the treatment of $4 \mathrm{~T} 1$ cells with guanylate cyclase $(\mathrm{GC})$ inhibitor 1-H-[1,2,4] oxadiaxolo[4,3-a]quinolalin-1-one (ODQ) reduced the migration of cells and the levels of cGMP. The presence of 8-bromoguanosine 3'5'-cyclic monophosphate, an analogue of cGMP, enhanced the migration of these cells, suggesting a role for $\mathrm{GC}$ in the migration of $4 \mathrm{~T} 1$ cells. Honokiol also inhibited the levels of cyclooxygenase-2 (COX-2) and prostaglandin (PG) $\mathrm{E}_{2}$ in $4 \mathrm{~T} 1$ cells. The transfection of $4 \mathrm{~T} 1$ cells with COX-2 siRNA resulted in a reduction in cell migration. ODQ and L-NAME also decreased the levels of $\mathrm{PGE}_{2}$ in 4T1 cells suggesting a role for $\mathrm{COX}-2 / \mathrm{PGE}_{2}$ in cell migration. Moreover, honokiol inhibited the activation of nuclear factor $\kappa \mathrm{B}(\mathrm{NF}-\mathrm{\kappa B})$, an upstream regulator of COX-2 and iNOS, in $4 \mathrm{~T} 1$ cells. These results indicate that $\mathrm{NO}$ and $\mathrm{COX}-2$ are the key targets of honokiol in the inhibition of breast cancer cell migration, an essential step in invasion and metastasis.
\end{abstract}

Correspondence to: Professor Santosh K. Katiyar, University of Alabama at Birmingham, 1670 University Boulevard, Volker Hall 557, Birmingham, AL 35294, USA

E-mail: skatiyar@uab.edu

Key words: cancer cell migration, cyclooxygenase-2, guanylate cyclase, nitric oxide, prostaglandin $\mathrm{E}_{2}$, breast cancer cells, honokiol

\section{Introduction}

It is expected that one in eight or thirteen out of one hundred women in the United States will develop breast cancer over the course of an entire lifetime. Breast cancer is the second most frequent cause of cancer-related death among women in the United States $(1,2)$. The metastatic spread of cancer continues to be the greatest barrier to a cure. Understanding the molecular mechanisms of metastasis is crucial for the effective therapeutic strategies to combat metastasis. Cancer cell migration is considered to be a major event in invasion and the metastatic cascade. Although breast cancer can be treated by using several available modalities, such as surgery, hormone therapy and radiation therapy (3), all these modalities may not work effectively in the advanced stages, where cancer cells have already metastasized to different parts of the body and the median survival time for most breast cancer patients is not more than a few years (3).

The role of nitric oxide (NO) in tumor biology has been extensively studied, and many studies have suggested a positive association between NO and tumor progression $(4,5)$. The production of NO at low levels is an important mediator of physiological functions, such as vasodilation, smooth muscle relaxation and the regulation of neurotransmission (6-8), while higher levels of NO can mediate antibacterial and antitumor functions. The chronic and sustained production of NO contributes to many pathological conditions, including inflammation-associated diseases and the development of cancers (8-10). In addition to its action as a cancer-initiating agent, $\mathrm{NO}$ can have an impact on various stages of carcinogenesis, such as invasiveness, metastasis and angiogenesis $(11,12)$. Studies have shown that NO promotes tumor cell migration, and that tumor cell migration requires the activation of NO synthase. They have also shown a positive association between endothelial-specific NO synthase expression in tumor cells and the growth and metastasis of tumors (4). These cancer-promoting effects have made NO a potential target for cancer chemoprevention.

Many studies have indicated that iNOS, as well as inducible cyclooxygenase-2 (COX)-2, are constitutively expressed in many cancers, suggesting that the indirect effect of $\mathrm{NO}$, through the regulation of COX activity, is present in 
COX-2 overexpressing cancers (13-16) in addition to its direct roles $(11,12)$. Until now, a number of interactions have been suggested between NOS and COX during inflammatory response. There are, however, conflicting reports with respect to whether NO activates or inhibits prostaglandin (PG) synthesis. Certain studies have suggested that during inflammation, NO upregulates COX-2 expression and increases COX-2 and COX-1 activity directly or indirectly (17-20), while others have reported that $\mathrm{NO}$ mediates COX inhibition (21-23). However, there are limited reports regarding cancer cell migration, particularly breast cancer cells, under the combined influence of $\mathrm{NO}$ and COX-2. As the role of COX-2 and NO induction in carcinogenesis has become among the most intensive areas of study in the metastasis of cancer cells, we examined the role of these biomarkers in mammary cancer cell migration in our in vitro model system of chemoprevention.

Honokiol $\left(\mathrm{C}_{18} \mathrm{H}_{18} \mathrm{O}_{2}\right)$ (Fig. 1) is an active constituent found in the bark and leaves of the Magnolia plant species. It is used in the traditional Japanese medicine, Saiboku-to, for the treatment of various ailments due to its anxiolytic, antithrombotic, anti-depressant and antibacterial properties (24). Honokiol has been shown to possess antibacterial, antiinflammatory, anti-oxidative and anti-carcinogenic properties (24-30). In this study, we examined the chemotherapeutic effects of honokiol on the migration of breast cancer cells, as the migration of cancer cells is a major event in the metastatic cascade of cancers. For this purpose, human breast cancer cells (MCF-7) and mouse mammary carcinoma cells (4T1) were used as an in vitro cancer model. We investigated the role of $\mathrm{NO}$ and COX-2 and its metabolite $\mathrm{PGE}_{2}$ on the migration of cancer cells and ascertained whether honokiol inhibits the migration of breast cancer cells and whether it is mediated through its action on $\mathrm{NO}$ and COX-2 expressions. We present evidence that honokiol inhibits breast cancer cell migration and that it does so through: (i) A reduction in the levels of NO production, inhibiting COX-2 expression and the production of $\mathrm{PGE}_{2}$ by cancer cells, and that (ii) this involves the downregulation of cyclic guanosine monophosphate (cGMP) and nuclear factor $\kappa \mathrm{B}(\mathrm{NF}-\kappa \mathrm{B})$, as shown in our in vitro cell culture model.

\section{Materials and methods}

Cells and cell culture conditions. The MCF-7 and 4T1 cells were obtained from the American Type Culture Collection (Rockville, Maryland) and cultured in monolayers in Dulbecco's Modified Eagle's Medium supplemented with $10 \%$ heat-inactivated fetal bovine serum, $100 \mu \mathrm{g} / \mathrm{ml}$ penicillin and $100 \mu \mathrm{g} / \mathrm{ml}$ streptomycin from Invitrogen (Carlsbad, CA) and maintained in a humidified incubator at $37^{\circ} \mathrm{C}$. Honokiol was dissolved in a small volume of ethanol, which was added to the complete cell culture medium [maximum concentration of ethanol, $0.02 \%(\mathrm{v} / \mathrm{v})$, in medium] prior to the addition to the subconfluent cells (60-70\% confluent). Cells treated with ethanol $(0.02 \%, \mathrm{v} / \mathrm{v})$ only served as the vehicle control.

Antibodies and reagents. Purified honokiol was procured from LKT Laboratories, Inc. (St. Paul, MN). Boyden chambers and polycarbonate membranes $(8 \mu \mathrm{m}$ pore size) for

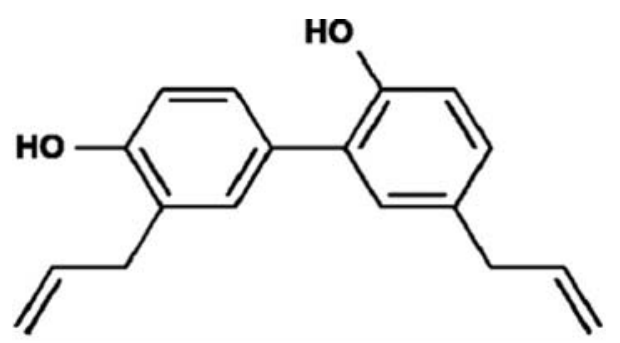

Figure 1. Molecular structure of honokiol, a phytochemical from the Magnolia species.

cell migration assays were obtained from Neuroprobe, Inc. (Gaithersburg, MD). The antibodies specific for COX-2, iNOS and their secondary antibodies were obtained from Cell Signaling Technology, Inc. (Beverly, MA). The $\mathrm{N}_{-}$ nitro-L-arginine methyl ester (L-NAME), D-NAME (inactive enantiomer of L-NAME) and 1-H-[1,2,4] oxadiazolo[4,3a]quinoxalin-1-one (ODQ), an inhibitor of guanylate cyclase (GC), an enzyme immunoassay kit for $\mathrm{PGE}_{2}$ analysis and the cyclic GMP EIA Kit, were obtained from Cayman Chemical Co. (Ann Arbor, MI). 8-Bromoguanosine 3'5'-cyclic monophosphate (8-Br cGMP), a cGMP analogue, was purchased from Sigma-Aldrich (St. Louis, MO).

Cell migration assay. The in vitro migration capacity of breast cancer cells and the inhibitory or stimulatory effects of any agent were determined using Boyden chambers in which two chambers were separated with Millipore membranes $(8-\mu \mathrm{m}$ pore size), as described previously (31). Briefly, cancer cells ( $1 \times 10^{4}$ cells $/ 100 \mu 1$ serum-reduced medium) were placed in the upper chamber of a Boyden apparatus. Honokiol or any other test agents were added alone or in combination to the upper chamber which contained cells, while the lower chamber contained the medium alone $(150 \mu 1)$. Boyden chambers with cells were kept in an incubator at $37^{\circ} \mathrm{C}$ for $24 \mathrm{~h}$. At the termination of the incubation period, cells from the upper surface of the Millipore membranes were completely removed with gentle swabbing and the migrant cells on the lower surface of the membranes were fixed and stained with crystal violet. The membranes were examined microscopically and cellular migration was determined by counting the number of cells on the membranes in at least 3-4 randomly selected fields using an Olympus BX41 microscope fitted with a Qcolor5 digital camera system. The cell migration experiment was repeated at least two times, and data are presented in terms of the number of migrating cells/microscopic field $\pm \mathrm{SD}$, at $\times 10$ magnification.

Measurement of NO in cell supernatants. In NO assay, nitrate is enzymatically converted into nitrite by the enzyme nitrate reductase and the nitrite is quantified using Griess reagent. Briefly, cell culture media were collected from cells treated identically to those used in the migration assays and stored at $-20^{\circ} \mathrm{C}$ until the assay. The levels of NO in cell culture supernatants were measured by determining the levels of their stable degradation products, nitrate and nitrite, using a colorimetric Nitric Oxide Assay Kit (Oxford Biomedical Research, Inc., Oxford, MI) following the manufacturer's instructions. 
$P G E_{2}$ immunoassay for quantification of $P G E_{2}$. The levels of $\mathrm{PGE}_{2}$ in cell homogenates were determined using the Cayman $\mathrm{PGE}_{2}$ Enzyme Immunoassay Kit following the manufacturer's instructions. Briefly, cells were harvested at the desired time-point and homogenized in $100 \mathrm{mM}$ phosphate buffer, $\mathrm{pH} 7.4$, containing $1 \mathrm{mM}$ ethylenediaminetetraacetic acid and $10 \mu \mathrm{M}$ indomethacin (a COX inhibitor) using a homogenizer. $\mathrm{PGE}_{2}$ concentration was determined in the supernatants according to the manufacturer's instructions.

COX-2-siRNA transfection of 4 T1 cells. COX-2 siRNA was transfected into 4T1 cells using the siRNA Transfection Reagent Kit (Santa Cruz Biotechnology, Inc., Santa Cruz, CA) according to the manufacturer's instructions. Briefly, $2 \times 10^{5}$ cells/well were seeded into a 6 -well plate and allowed to grow to $70 \%$ confluency. The COX-2 siRNA mix with transfection reagents was overlaid on the cells for $\sim 6 \mathrm{~h}$ at $37^{\circ} \mathrm{C}$ and transferred into $2 \mathrm{X}$ growth medium for $\sim 18-20 \mathrm{~h}$. At $24 \mathrm{~h}$ post-transfection, fresh medium was added to the cells, and the cells were incubated for an additional $48 \mathrm{~h}$. The knockdown of COX-2 expression in the cells after transfection was confirmed by Western blot analysis. Thereafter, the cells were subjected to cell migration assay.

$N F-\kappa B / p 65$ activity assay. Quantitative analysis of NF-кB/ p65 activity was performed using the NF- $\kappa$ B Trans ${ }^{\mathrm{AM}}$ Activity Assay Kit (Active Motif, Carlsbad, CA) following the manufacturer's instructions. For this assay, the nuclear extracts from cells were prepared using the Nuclear Extraction Kit (Active Motif) according to the manufacturer's instructions. Absorbance was recorded at $450 \mathrm{~nm}$ using the absorbance at $650 \mathrm{~nm}$ as the reference. The results are expressed as the percentage of the optical density of the control (non-honokiol-treated) group.

Western blot analysis. Breast cancer cells were treated with or without honokiol or any other agent for the desired time period. Thereafter the cells were harvested and lysed with ice-cold lysis buffer supplemented with protease inhibitors, as described previously $(32,33)$. Proteins were resolved on $10 \%$ Tris-Glycine gels and transferred onto a nitrocellulose membrane. After blocking the non-specific binding sites, the membrane was incubated with the primary antibody at $4^{\circ} \mathrm{C}$ overnight, washed and then incubated with the peroxidaseconjugated secondary antibody and the specific protein bands were detected using enhanced chemiluminescence reagents. To verify equal protein loading, the membrane was stripped and reprobed with anti- $\beta$ actin antibody.

Statistical analysis. For cell migration assays, the control, honokiol- or ODQ-treated groups were compared separately using one-way analysis of variance (ANOVA). All quantitative data are shown as the means \pm SD. In each case a value of $\mathrm{P}<0.05$ was considered to be statistically significant.

\section{Results}

Honokiol inhibits the migration of breast cancer cells by inhibiting the endogenous levels of NO. Before performing cell migration assay, preliminary experiments were performed to determine the effects of lower concentrations of honokiol on cell viability and cell death using trypan blue exclusion assays, as described previously $(32,33)$. Only those in vitro concentrations of honokiol were selected which did not significantly inhibit cell viability or induce cell death as that could adversely affect the cancer cell migration. The molecular structure of honokiol is shown in Fig. 1. As shown in Fig. 2, relative to the untreated control cells, treatment of cells with honokiol for $24 \mathrm{~h}$ at the concentrations of 5, 10 and $20 \mu \mathrm{M}$ reduced the cell migration capacity of MCF-7 and 4T1 cells in a concentration-dependent manner. The density of the migrating cells on the membrane after staining with crystal violet dye is shown in Fig. 2A, and the numbers of migrating cells/microscopic field are summarized in Fig. 2B. The cell migration was inhibited by $18-65 \%$ in MCF-7 cells and by $28-82 \%$ in $4 \mathrm{~T} 1$ cells in a concentration-dependent manner after treatment with honokiol.

In order to determine whether the inhibitory effect on the migration of cancer cells was due to the inhibition of NO production by honokiol, the levels of NO in cell supernatants of the various treatment groups were determined. It was observed that the treatment of MCF-7 and 4T1 cells with honokiol $(5-20 \mu \mathrm{M})$ resulted in a significant reduction in the levels of NO production in a dose-dependent manner compared to the non-honokiol-treated control cells (Fig. 2C). As the levels of NO decreased after honokiol treatment, we determined whether the levels of NOS were reduced in the honokiol-treated cells. Western blot analysis revealed that the treatment of MCF-7 and 4T1 cells with honokiol decreases the expression of iNOS in these cells in a dose-dependent manner (Fig. 2D). These results also reveal that the migrating capacity of murine mammary carcinoma cells (4T1) is greater than that of human breast cancer cells MCF-7. Also, 4T1 cells are considered to be highly metastasis-specific cancer cells. Therefore, further studies were conducted with only 4T1 cells to determine the mechanism of inhibition of cell migration by honokiol.

L-NAME, an inhibitor of NO, inhibits breast cancer cell migration. L-NAME is a well known inhibitor of NOS, and thus an inhibitor of NO production. We therefore examined the effect of L-NAME on the migrating capacity of 4T1 cells using cell migration assay. The treatment of $4 \mathrm{~T} 1$ cells with L-NAME at concentrations of 250,500 and $1000 \mu \mathrm{M}$ for $24 \mathrm{~h}$ resulted in a significant inhibition of cell migration in a concentration-dependent manner $(42 \pm 5-76 \pm 5 \%, \mathrm{P}<0.01$ $0.001)$, compared to the non-L-NAME-treated control $4 \mathrm{~T} 1$ cells. Resultant data on number of migrating cells/microscopic field from three independent experiments are summarized as the means \pm SD (Fig. 3A). Treatment of cells with D-NAME (an inactive enantiomer of L-NAME) for $24 \mathrm{~h}$ did not result in the inhibition of cell migration and did not reduce the levels of NO in the cell supernatants (data not shown).

Honokiol decreases the basal levels of cGMP in $4 T 1$ cells. NO stimulates the GC/cGMP pathway in a variety of cancer cells and thus affects cell migration (34). We determined whether honokiol has any effect on the levels of cGMP in mammary cancer cells. The treatment of $4 \mathrm{~T} 1$ cells with honokiol $(5,10$ and $20 \mu \mathrm{M})$ for $24 \mathrm{~h}$ resulted in a dose- 
A
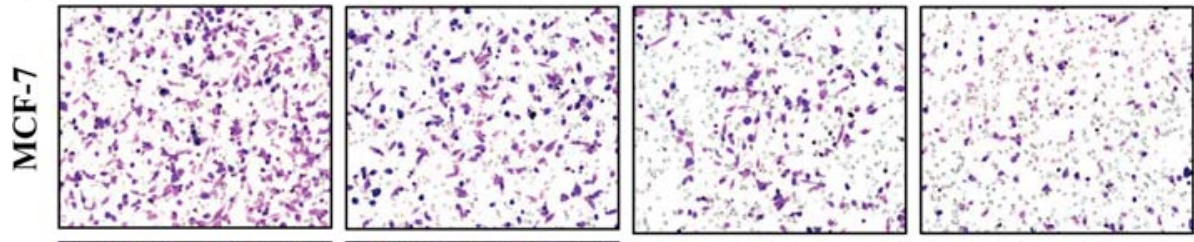

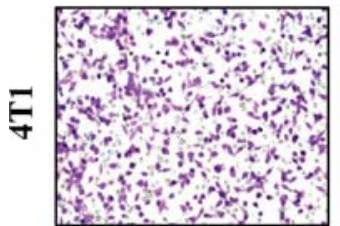

0
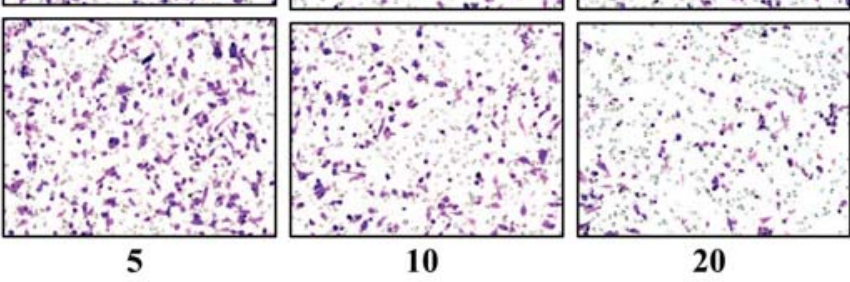

Honokiol Conc. $(\mu \mathrm{M})$

B

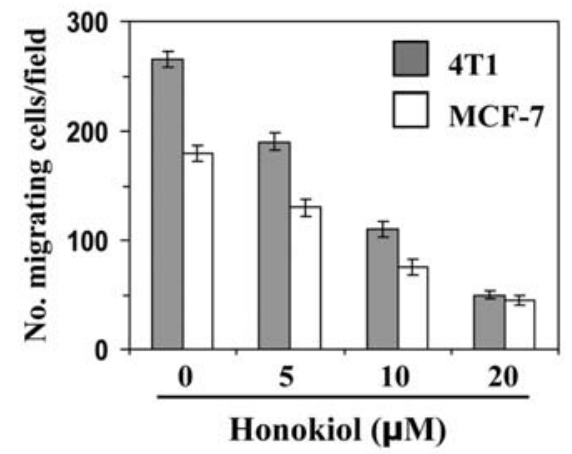

D

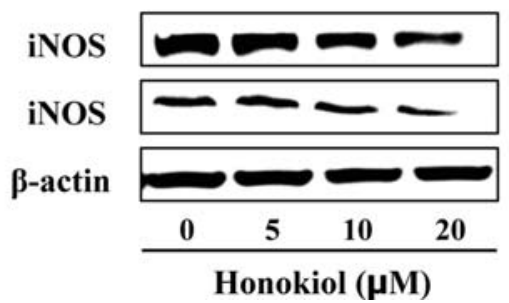

C

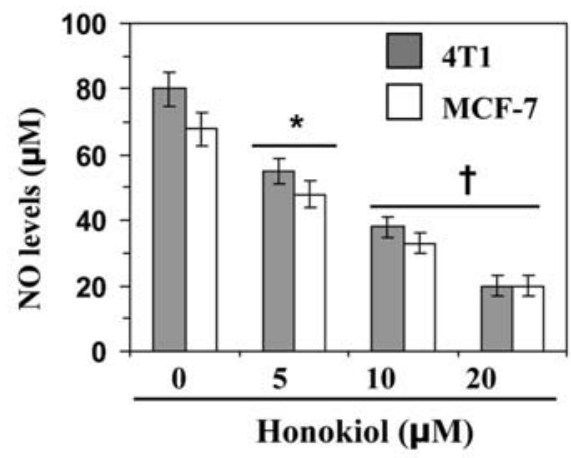

4T1

MCF-7

Figure 2. Treatment of breast cancer cells with honokiol inhibits the migration of cells. (A) Treatment of human breast cancer cells MCF-7 and mouse mammary carcinoma cells 4T1 with honokiol inhibits the migration of cells in a dose-dependent manner. (B) The number of migrating cells was counted in each group and the results are expressed as the mean number of migratory cells \pm SD/microscopic field. (C) Effect of honokiol on the levels of NO. The levels of $\mathrm{NO}$ were determined in cell supernatants using the Nitric Oxide Assay Kit, and data are shown as the means \pm SD from three independent experiments. Significant inhibition by honokiol versus non-honokiol-treated controls, ${ }^{*} \mathrm{P}<0.05 ;{ }^{\dagger} \mathrm{P}<0.001$. (D) The levels of iNOS expression were determined in cell lysates from MCF-7 and 4T1 cells by Western blot analysis.

dependent decrease in the levels of cGMP $(17 \pm 2-83 \pm 6 \%$, Fig. 3B) compared to the non-honokiol-treated control. To determine the role of cGMP on cell migration, certain agents which are known to block cGMP formation (e.g. ODQ, a GC inhibitor) or mimic cGMP action (8-Br cGMP, a cell permeable cGMP analogue) were used. As shown in Fig. 3C, the treatment of $4 \mathrm{~T} 1$ cells with ODQ for $24 \mathrm{~h}$ resulted in a significant reduction in the levels of cGMP $(33 \pm 3-82 \pm 4 \%$, $\mathrm{P}<0.01-0.001)$ in the cell supernatants similar to that observed with the treatment of the cells with honokiol (Fig. 3B). The treatment of 4T1 cells with ODQ $(25,50$ and $100 \mu \mathrm{M})$ also resulted in a significant inhibition of cell migration in a dosedependent manner (20-76\%, P<0.01-0.001) (Fig. 3D). The treatment of cells with 8 -Br cGP (cGMP analogue) increased the numbers of migrating cells (Fig. 3E) under identical conditions, suggesting a role for cGMP in mammary cancer cell migration.
The inhibition of cell migration by honokiol is associated with the inhibition of endogenous $\mathrm{COX}-2$ expression and $P G E_{2}$ production. As the overexpression of COX-2 has been shown to stimulate invasion and metastasis in cancer cells, we determined whether the inhibitory effect of honokiol on the migration of the cells is associated with inhibition of COX-2 expression. We determined the levels of COX-2 expression in lysates of cells from the various treatment groups by Western blot analysis. As shown in Fig. 4A, treatment of 4T1 cells with honokiol reduced the levels of COX-2 expression in a concentration-dependent manner compared to the expression in the untreated controls. As the COX-2 metabolite, $\mathrm{PGE}_{2}$, has been implicated in COX-2mediated effects, we determined the levels of $\mathrm{PGE}_{2}$ in the honokiol-treated cells. Immunoassay data on $\mathrm{PGE}_{2}$ revealed that treatment of $4 \mathrm{~T} 1$ cells with honokiol for $24 \mathrm{~h}$ resulted in 


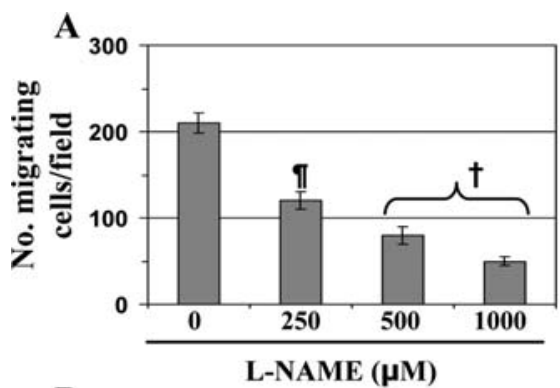

B

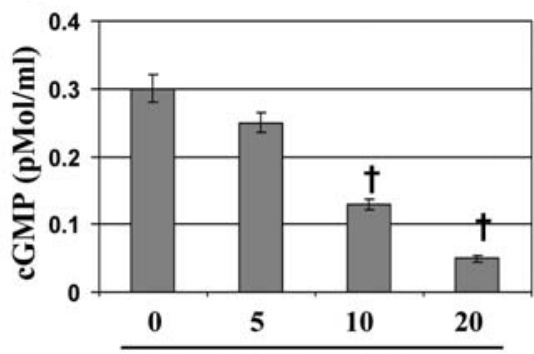

Honokiol Conc. $(\mu \mathrm{M})$

$$
\text { D }
$$

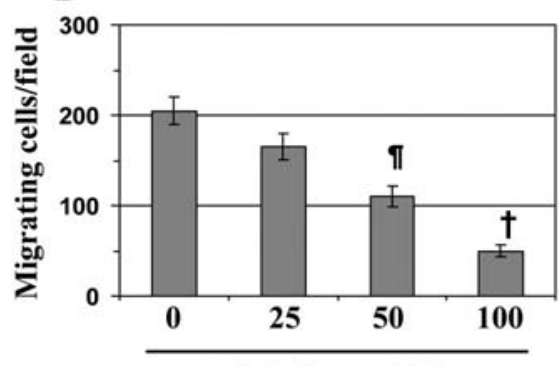

ODQ Conc. $(\mu \mathrm{M})$

\section{C}

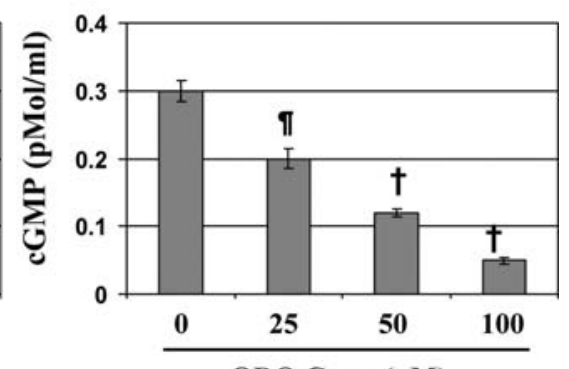

ODQ Conc. $(\mu \mathrm{M})$

$\mathbf{E}$

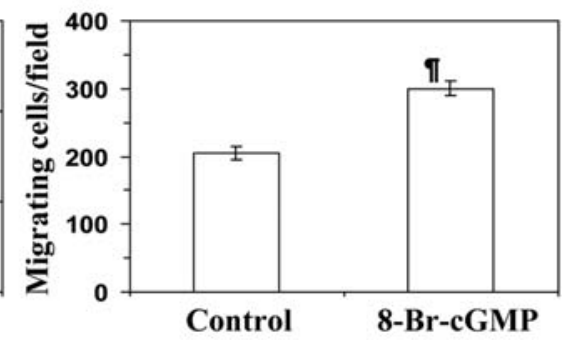

Figure 3. (A) Treatment of 4T1 cells with L-NAME inhibits the migration of 4T1 cells. The numbers of migratory cells/microscopic field are summarized as the means \pm SD, n=3. (B) Treatment of cells with honokiol for $24 \mathrm{~h}$ decreases the levels of cGMP in a dose-dependent manner. (C) Treatment of cells with ODQ, an inhibitor of GC, decreases the levels of cGMP. (D) Treatment of cells with ODQ inhibits the migration of 4T1 cells in a dose-dependent manner. (E) Treatment of 8-Br cGMP, an analogue of cGMP, increases the migrating capacity of $4 \mathrm{~T} 1$ cells. Significant difference versus the untreated controls, ${ }^{9} \mathrm{P}<0.01$; ${ }^{+} \mathrm{P}<0.001$

significant inhibition of $\mathrm{PGE}_{2}$ production $(18-68 \%, \mathrm{P}<0.05-$ 0.001 ) in a concentration-dependent manner (Fig. 4B), suggesting that the honokiol-induced reduction in $\mathrm{PGE}_{2}$ production is associated with an inhibitory effect on COX-2 activity by honokiol in these mammary cancer cells.

siRNA knockdown of COX-2 leads to reduction of $4 T 1$ cell migration. We further verified the role of COX-2 in breast cancer cell migration through siRNA knockdown of COX-2 in the 4T1 cells and examined whether it could lead to the inhibition of cell migration in these cells. The transfection of 4T1 cells with COX-2 siRNA resulted in a significant reduction in cell migration in 4T1 cells $(86 \%, \mathrm{P}<0.001)$ after $24 \mathrm{~h}$ compared to the migration of the control siRNA-transfected 4T1 cells (Fig. 4C).

$O D Q$ and $L-N A M E$ reduced the levels of $P G E_{2}$ in $4 T 1$ cells. In order to determine whether ODQ and L-NAME affect cell migration through their inhibitory effect on $\mathrm{PGE}_{2}$ production, in addition to their effect on NO, 4T1 cells were treated with ODQ or L-NAME for $24 \mathrm{~h}$, and the levels of $\mathrm{PGE}_{2}$ were determined. As shown in Fig. 4D, the treatment of cells with ODQ significantly inhibited $(\mathrm{P}<0.001)$ the production of the
$\mathrm{PGE}_{2}$ metabolite in a concentration-dependent manner. A similar inhibitory effect on $\mathrm{PGE}_{2}$ production was also found when the cells were treated with L-NAME (Fig. 4E). These data suggest that there is an interrelationship between NO and COX-2 expressions and that both have an effect on cancer cell migration.

Honokiol reduces the activation of $N F-\kappa B / p 65$ in $4 T 1$ cells: $N F-\kappa B$ is an important regulator of $C O X-2$ and $i N O S$. iNOS and COX-2 are downstream targets of $\mathrm{NF}-\kappa \mathrm{B}$ or $\mathrm{NF}-\kappa \mathrm{B}$ is a regulator of COX-2 and iNOS expression. Therefore we assessed whether honokiol affects the level of NF-кB in 4T1 cells. For this purpose, cells were treated with various concentrations of honokiol $(0,5,10$ and $20 \mu \mathrm{M})$ for $24 \mathrm{~h}$, and thereafter the cells were harvested and nuclear fractions were subjected to Western blot analysis. The results of Western blot analysis revealed that the treatment of cells with honokiol downregulated the translocation of $\mathrm{NF}-\kappa \mathrm{B} / \mathrm{p} 65$ from the cytosol to the nucleus in a dose-dependent manner (Fig. 5A). The activity of NF- $\mathrm{KB}$ was also significantly reduced (25-80\%, $\mathrm{P}<0.05$ and $\mathrm{P}<0.001)$ after the treatment of cells with honokiol (Fig. 5B). In order to examine whether $\mathrm{NF}-\mathrm{\kappa B}$ has a role in breast cancer cell migration, 4T1 cells were treated with 
$\mathbf{A}$

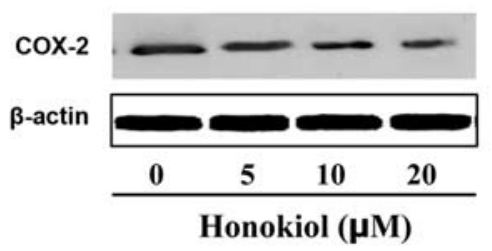

C

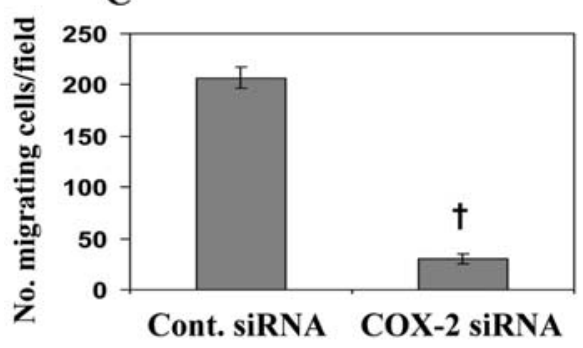

$\mathbf{E}$

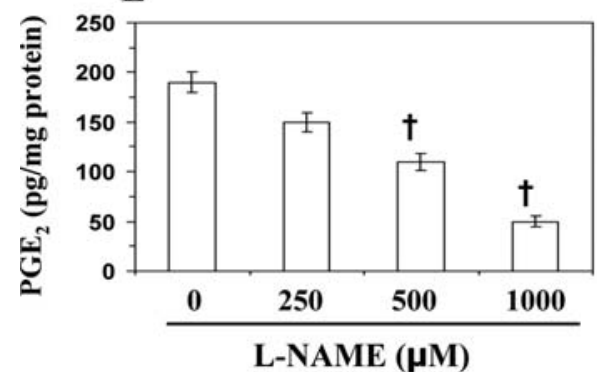

B

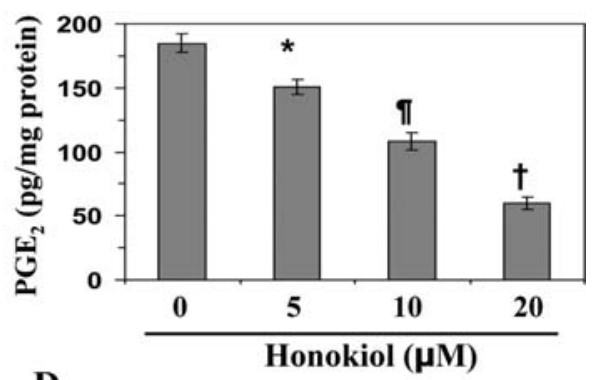

D

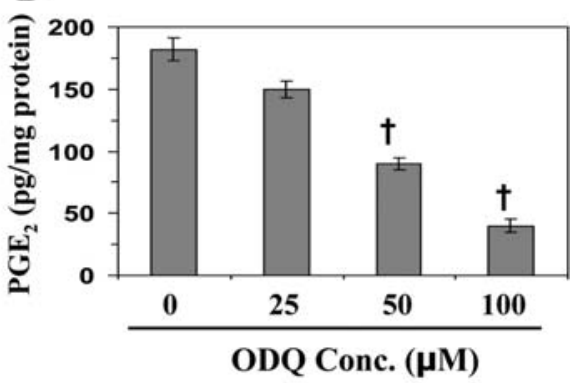

Figure 4. (A) Honokiol reduces the basal levels of COX-2 in 4T1 cells. The levels of COX-2 were determined in cell lysates by Western blot analysis. (B) Dose-dependent effect of honokiol on the levels of $\mathrm{PGE}_{2}$ in cell lysates. The levels of $\mathrm{PGE}_{2}$ are expressed in terms of $\mathrm{pg} / \mathrm{mg} \mathrm{protein} \pm \mathrm{SD}, \mathrm{n}=3$ independent experiments. Significant inhibition by honokiol versus the non-honokiol-treated controls, ${ }^{*} \mathrm{P}<0.05$; ${ }^{\mathrm{S}} \mathrm{P}<0.01$; ${ }^{\dagger} \mathrm{P}<0.001$. (C) Transfection of $4 \mathrm{~T} 1$ cells with COX-2 siRNA significantly decreases cell migration. Cells were transfected with COX-2 siRNA to knockdown COX-2 expression. Significant reduction of cell migration versus the control siRNA-treated cells: ${ }^{\dagger} \mathrm{P}<0.001$. Treatment of $4 \mathrm{~T} 1$ cells with ODQ (D) or L-NAME (E) for $24 \mathrm{~h}$ inhibits the production of $\mathrm{PGE}_{2}$ in a dose-dependent manner. Significant inhibition by honokiol, ODQ or L-NAME versus the non-treated controls, ${ }^{+} \mathrm{P}<0.001$.

various concentrations of caffeic acid phenethyl ester $(0,5$ and $10 \mu \mathrm{g} / \mathrm{ml}$ ), a potent inhibitor of NF- $\mathrm{BB}$, and cell migration was determined. As shown in Fig. 5C, the treatment of cells with caffeic acid phenethyl ester resulted in a significant reduction in cell migration (47 and $83 \%, \mathrm{P}<0.001)$ relative to the untreated control cells, similar to that observed with the treatment of cells with honokiol (Fig. 2A). Cell migration data are summarized in Fig. 5D.

\section{Discussion}

Understanding the molecular mechanisms of cancer cell metastasis is crucial for the effective therapeutic strategies to combat metastasis and the successful treatment of breast cancer. Endogenous NO promotes tumor progression and metastasis through multiple pathways, which include the stimulation of tumor angiogenesis, invasiveness and tumor cell migration $(34,35)$. Similarly, many human cancers express elevated levels of COX-2. The COX-2 overexpression and abundant production of $\mathrm{PGE}_{2}$ have been linked with tumor progression, invasion and metastasis (36). Due to their important roles in tumor invasion and metastasis, NO and
COX-2 are considered to be promising targets for cancer therapy $(36,37)$.

The significant findings in the present study are that the treatment of breast cancer cells with honokiol inhibits cell migration in a dose-dependent manner, and that this is associated with the inhibition of NO production, COX-2 overexpression and $\mathrm{PGE}_{2}$ synthesis. Our study reveals that the inhibition of cancer cell migration by honokiol is mediated through the reduction in the levels of endogenous $\mathrm{NO}$ in both MCF-7 and 4T1 cells. The reduction in NO levels by honokiol is due to the inhibition of NOS expression in cells. NO-mediated migration also was blocked by the use of L-NAME, validating the NO-mediated stimulation of tumor cell migration and demonstrating that the migrationinhibitory effects of honokiol are NO-specific. Studies have shown that NO activates soluble GC and elevates cGMP, which affects the biological responses of NO via the activation of cGMP-dependent protein kinase or by modulating the phosphodiesterase activity $(38,39)$. We provide evidence that the NO-mediated stimulation of mammary cancer cell migration is cGMP-dependent, showing that: (i) The cGMP analogue, 8-Br cGMP, which mimicked the migration- 
$\mathbf{A}$

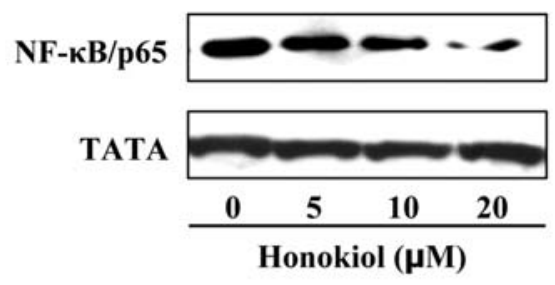

C

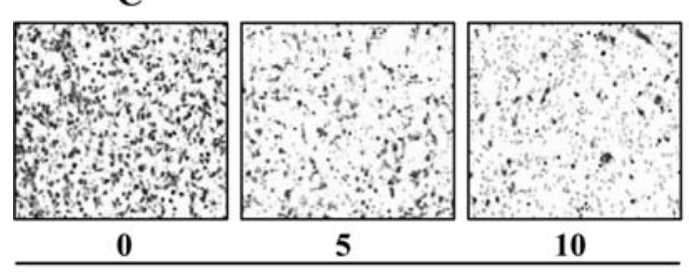

CAPE $(\mu \mathrm{g} / \mathrm{ml})$
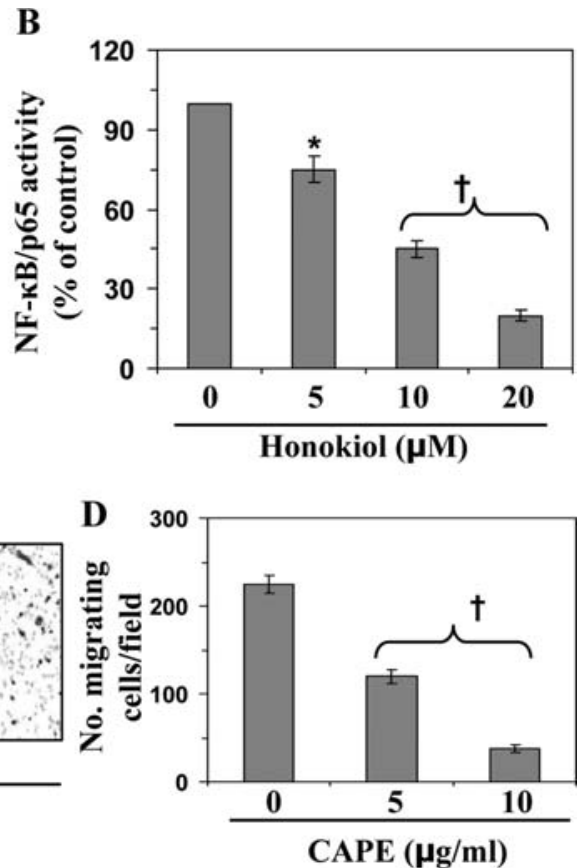

Figure 5. Treatment of 4T1 cells with honokiol decreases the activation or translocation of NF- $\mathrm{B} / \mathrm{p} 65$ to the nucleus. (A) After 24-h treatment with various concentrations of honokiol the cells were harvested and nuclear fractions were prepared and levels of NF- $\mathrm{B} / \mathrm{p} 65 \mathrm{were}$ analyzed by Western blot analysis. A representative blot is shown from three independent experiments with identical observations. (B) The activity of NF- $\mathrm{B} / \mathrm{p} 65$ in the nuclear fraction of cells after treatment with or without honokiol for $24 \mathrm{~h}$ was measured using the NF- $\mathrm{kB} / \mathrm{p} 65$-specific activity assay kit, $\mathrm{n}=3$. Activity of NF- $\mathrm{kB}$ is expressed in terms of the percentage of the control (non-honokiol-treated) group. Significant decrease versus the control, ${ }^{*} \mathrm{P}<0.05$ and ${ }^{\dagger} \mathrm{P}<0.001$. (C) Treatment of cells with caffeic acid phenethyl ester (CAPE), an inhibitor of NF- $\mathrm{KB}$, for $24 \mathrm{~h}$ inhibits cell migration. (D) Data on cell migration capacity are summarized as the mean number of migratory cells $\pm \mathrm{SD} /$ microscopic field, $n=3$. Significant inhibition versus the non-CAPE-treated cells: ${ }^{\dagger} \mathrm{P}<0.001$.

promoting role of $\mathrm{NO}$, has migration inhibitory effects. (ii) A selective inhibitor of soluble GC, ODQ, inhibited 4T1 cell migration, attesting to the GC selectivity of ODQ in the migration-inhibitory response. Under identical experimental conditions, the treatment of 4T1 cells with honokiol reduced the basal levels of cGMP and these effects were similar to those of ODQ in this in vitro cell culture model. These observations support the evidence that the inhibition of cancer cell migration by honokiol requires the inhibition of cGMP.

Another important finding of this study is that the inhibition of 4T1 cell migration by honokiol is associated with the inhibition of COX-2 expression and $\mathrm{PGE}_{2}$ production. The mammary cancer cells overexpress COX-2, and the inhibition of COX-2 by honokiol can contribute to the inhibition of cell migration of these cells. This concept is supported by the evidence that the transfection of 4T1 cells with murine COX-2 siRNA resulted in a significant reduction in cell migration. Many of the carcinogenic effects of COX-2 are mediated through its metabolite, $\mathrm{PGE}_{2}$. Honokiol inhibits $\mathrm{PGE}_{2}$ production in $4 \mathrm{~T} 1$ cells. These observations support the evidence that the inhibition of 4T1 cell migration by honokiol also requires the downregulation of $\mathrm{COX}-2$ expression.

The interaction between NOS and COX-2 has been reported mainly in cells involved in inflammatory responses, such as activated macrophage-like cells $(17,40)$. These studies have suggested that the COX-2 regulation by NO occurred through the modulating effects of transcription factors, such as NF-кB $(41,42)$. We found that the treatment of $4 \mathrm{~T} 1$ cells with ODQ or L-NAME decreased the levels of
$\mathrm{PGE}_{2}$, while ODQ and L-NAME also reduced the migration of cells and decreased the basal levels of NO in these cells. These results suggest that cross-talk exists between COX-2 and NOS in breast cancer cell migration. These findings indicate that endogenous $\mathrm{NO}$, which is produced by $4 \mathrm{~T} 1$ cells, plays an important role in COX-2 upregulation and $\mathrm{PGE}_{2}$ production. Thus, it can by hypothesized that the continuous upregulation of COX-2 and NOS could facilitate cancer cell migration.

$\mathrm{NF}-\kappa \mathrm{B}$ is a regulator of COX-2 and iNOS. Certain studies have suggested that the $\mathrm{COX}-2$ regulation by $\mathrm{NO}$ occurs through the transcription factor NF- $\mathrm{KB}$. We therefore examined the effect of honokiol on the basal levels as well as the activity of NF- $\mathrm{KB}$ in $4 \mathrm{~T} 1$ cells, and found that the treatment of 4T1 cells with honokiol downregulates the basal level as well as the activity of NF- $\mathrm{kB} / \mathrm{p} 65$ in a dose-dependent manner. Treatment of 4T1 cells with caffeic acid phenethyl ester, an inhibitor of NF-кB, resulted in an inhibitory effect on 4T1 cell migration. These observations further support the concept that the inhibitory effect of honokiol on breast cancer cell migration is mediated through the downregulation of the expressions of $\mathrm{NO}, \mathrm{COX}-2, \mathrm{PGE}_{2}$ and transcription factor $\mathrm{NF}-\kappa \mathrm{B}$.

In summary, our study shows that honokiol inhibits the migration of breast cancer cells by targeting NO and COX-2, and successively downregulates the migration-promoting signals induced by NO and COX-2. More mechanism-based studies using in vivo models are required in order to develop honokiol as a pharmacologically safe agent alone, or in combination with other anti-metastatic drugs, for the treatment of metastatic breast cancer. 


\section{Acknowledgements}

This study was supported by funds from the Veterans Administration Merit Review Award (S.K.K.).

\section{References}

1. American Cancer Society: Cancer facts and figures. Atlanta, GA. American Cancer Society, 2009.

2. Jemal A, Murray T, Ward E, Samuels A, Tiwari RC, Ghafoor A, Feuer EJ and Thun MJ: Cancer statistics, 2005. CA Cancer J Clin 55: 10-30, 2005.

3. Ali SM, Harvey HA and Lipton A: Metastatic breast cancer: overview of treatment. Clin Orthop Relat Res (Suppl) 415: 132-137, 2003

4. Lala PK and Orucevic A: Role of nitric oxide in tumor progression: lessons from experimental tumors. Cancer Metastasis Rev 17: 91-106, 1998.

5. Thomsen LL and Miles DW: Role of nitric oxide in tumour progression: lessons from human tumours. Cancer Metastasis Rev 17: 107-118, 1998

6. Moncada S and Higgs EA: The L-arginine-nitric oxide pathway N Engl J Med 329: 2002-2012, 1993.

7. Knowles RG and Moncada S: Nitric oxide synthases in mammals. Biochem J 298: 249-258, 1994.

8. Lala PK and Chakraborty C: Role of nitric oxide in carcinogenesis and tumour progression. Lancet Oncol 2: 149-156, 2001.

9. Jenkins DC, Charles IG, Thomsen LL, Moss DW, Holmes LS, Baylis SA, Rhodes P, Westmore K, Emson PC and Moncada S: Roles of nitric oxide in tumor growth. Proc Natl Acad Sci USA 92: 4392-4396, 1995.

10. Gallo O, Masini E, Morbidelli L, Franchi A, Fini-Storchi I, Vergari WA and Ziche M: Role of nitric oxide in angiogenesis and tumor progression in head and neck cancer. J Natl Cancer Inst 90: 587-596, 1998 .

11. Wink DA, Vodovotz Y, Laval J, Laval F, Dewhirst MW and Mitchell JB: The multifaceted roles of nitric oxide in cancer. Carcinogenesis 19: 711-721, 1998

12. Surh YJ, Chun KS, Cha HH, Han SS, Keum YS, Park KK and Lee SS: Molecular mechanisms underlying chemopreventive activities of anti-inflammatory phytochemicals: down-regulation of COX-2 and iNOS through suppression of NF-kappa B activation. Mutat Res 480-481: 243-268, 2001.

13. Rajnakova A, Moochhala S, Goh PM and Ngoi S: Expression of nitric oxide synthase, cyclooxygenase, and p53 in different stages of human gastric cancer. Cancer Lett 172: 177-185, 2001.

14. Uotila P, Valve E, Martikainen P, Nevalainen M, Nurmi M and Härkönen P: Increased expression of cyclooxygenase-2 and nitric oxide synthase- 2 in human prostate cancer. Urol Res 29: 23-28, 2001

15. Wilson KT, Fu S, Ramanujam KS and Meltzer SJ: Increased expression of inducible nitric oxide synthase and cyclooxygenase-2 in Barrett's esophagus and associated adenocarcinomas. Cancer Res 58: 2929-2934, 1998.

16. Ambs S, Merriam WG, Bennett WP, Felley-Bosco E, Ogunfusika MO, Oser SM, Klein S, Shields PG, Billiar TR and Harris CC: Frequent nitric oxide synthase-2 expression in human colon adenomas: implication for tumor angiogenesis and colon cancer progression. Cancer Res 58: 334-341, 1998.

17. Salvemini D, Misko TP, Masferrer JL, Seibert K, Currie MG and Needleman P: Nitric oxide activates cyclooxygenase enzymes. Proc Natl Acad Sci USA 90: 7240-7244, 1993.

18. Salvemini D, Seibert K, Masferrer JL, Misko TP, Currie MG and Needleman P: Endogenous nitric oxide enhances prostaglandin production in a model of renal inflammation. J Clin Invest 93: 1940-1947, 1994.

19. Amin AR, Attur M, Patel RN, Thakker GD, Marshall PJ, Rediske J, Stuchin SA, Patel IR and Abramson SB: Superinduction of cyclooxygenase-2 activity in human osteoarthritisaffected cartilage. Influence of nitric oxide. J Clin Invest 99: 1231-1237, 1997

20. Davidge ST, Baker PN, Laughlin MK and Roberts JM: Nitric oxide produced by endothelial cells increases production of eicosanoids through activation of prostaglandin $\mathrm{H}$ synthase. Circ Res 77: 274-283, 1995.

21. Kanner J, Harel S and Granit R: Nitric oxide, an inhibitor of lipid oxidation by lipoxygenase, cyclooxygenase and hemoglobin. Lipids 27: 46-49, 1992.
22. Stadler J, Harbrecht BG, DiSilvio M, Curran RD, Jordan ML, Simmons RL and Billiar TR: Endogenous nitric oxide inhibits the synthesis of cyclooxygenase products and interleukin- 6 by rat Kupffer cells. J Leukoc Biol 53: 165-172, 1993.

23. Tsai AL, Wei C and Kulmacz RJ: Interaction between nitric oxide and prostaglandin $\mathrm{H}$ synthase. Arch Biochem Biophys 313: 367-372, 1994.

24. Li TSC: Chinese and Related North American Herbs. In: Phytopharmacology and Therapeutic Values. CRC Press, Boca Raton, FL, 2002.

25. Hahm ER, Arlotti JA, Marynowski SW and Singh SV: Honokiol, a constituent of oriental medicinal herb magnolia officinalis, inhibits growth of PC-3 xenografts in vivo in association with apoptosis induction. Clin Cancer Res 14: 1248-1257, 2008

26. Bai X, Cerimele F, Ushio-Fukai M, Waqas M, Campbell PM, Govindarajan B, Der CJ, Battle T, Frank DA, Ye K, Murad E, Dubiel W, Soff G and Arbiser JL: Honokiol, a small molecular weight natural product, inhibits angiogenesis in vitro and tumor growth in vivo. J Biol Chem 278: 35501-35507, 2003.

27. Munroe ME, Arbiser JL and Bishop GA: Honokiol, a natural plant product, inhibits inflammatory signals and alleviates inflammatory arthritis. J Immunol 179: 753-763, 2007.

28. Pyo MK, Lee Y and Yun-Choi HS: Anti-platelet effect of the constituents isolated from the barks and fruits of Magnolia obovata. Arch Pharm Res 25: 325-328, 2002.

29. Clark AM, El-Feraly FS and Li WS: Antimicrobial activity of phenolic constituents of Magnolia grandiflora L. J Pharm Sci 70: 951-952, 1981

30. Park J, Lee J, Jung E, Park Y, Kim K, Park B, Jung K, Park E, Kim $J$ and Park D: In vitro antibacterial and anti-inflammatory effects of honokiol and magnolol against Propionibacterium sp. Eur J Pharmacol 496: 189-195, 2004.

31. Punathil $\mathrm{T}$ and Katiyar SK: Inhibition of non-small cell lung cancer cell migration by grape seed proanthocyanidins is mediated through the inhibition of nitric oxide, guanylate cyclase, and ERK1/2. Mol Carcinog 48: 232-242, 2009.

32. Akhtar S, Meeran SM, Katiyar N and Katiyar SK: Grape seed proanthocyanidins inhibit the growth of human non-small cell lung cancer xenografts by targeting IGFBP-3, tumor cell proliferation and angiogenic factors. Clin Cancer Res 15: 821-831, 2009.

33. Mantena SK, Sharma SD and Katiyar SK: Berberine inhibits growth, induces G1 arrest and apoptosis in human epidermoid carcinoma A431 cells by regulating Cdki-Cdk-cyclin cascade, disruption of mitochondrial membrane potential and cleavage of caspase-3 and PARP. Carcinogenesis 27: 2018-2027, 2006.

34. Jadeski LC, Hum KO, Chakraborty $\mathrm{C}$ and Lala PK: Nitric oxide promotes murine mammary tumour growth and metastasis by stimulating tumour cell migration, invasiveness and angiogenesis. Int J Cancer 86: 30-39, 2000.

35. Orucevic A, Bechberger J, Green AM, Shapiro RA, Billiar TR and Lala PK: Nitric-oxide production by murine mammary adenocarcinoma cells promotes tumor-cell invasiveness. Int $\mathbf{J}$ Cancer 81: 889-896, 1999.

36. Dannenberg AJ and Subbaramaiah K: Targeting cyclooxygenase-2 in human neoplasia: rationale and promise. Cancer Cell 4: 431-436, 2003.

37. Riedl K, Krysan K, Põld M, Dalwadi H, Heuze-Vourc'h N, Dohadwala M, Liu M, Cui X, Figlin R, Mao JT, Strieter R, Sharma S and Dubinett SM: Multifaceted roles of cyclooxygenase-2 in lung cancer. Drug Resist Updat 7: 169-184, 2004.

38. Moncada S, Palmer RM and Higgs EA: Nitric oxide: physiology, pathophysiology, and pharmacology. Pharmacol Rev 43: 109-142, 1991.

39. Méry PF, Pavoine C, Belhassen L, Pecker F and Fischmeister R: Nitric oxide regulates cardiac $\mathrm{Ca}^{2+}$ current. Involvement of cGMPinhibited and cGMP-stimulated phosphodiesterases through guanylyl cyclase activation. J Biol Chem 268: 26286-26295, 1993.

40. Habib A, Bernard C, Lebret M, Creminon C, Esposito B, Tedgui A and Maclouf J: Regulation of the expression of cyclooxygenase- 2 by nitric oxide in rat peritoneal macrophages. $\mathrm{J}$ Immunol 158: 3845-3851, 1997

41. Liaudet L, Soriano FG and Szabó C: Biology of nitric oxide signaling. Crit Care Med 28: N37-N52, 2000.

42. D'Acquisto F, Maiuri MC, de Cristofaro F and Carnuccio R: Nitric oxide prevents inducible cyclooxygenase expression by inhibiting nuclear factor-kappa B and nuclear factor-interleukin-6 activation. Naunyn Schmiedebergs Arch Pharmacol 364: 157-165, 2001. 